\title{
Influence of CD40 rs1883832 Polymorphism in Susceptibility to and Clinical Manifestations of Biopsy-proven Giant Cell Arteritis
}

\author{
LUIS RODRÍGUEZ-RODRÍGUEZ, SANTOS CASTAÑEDA, TOMÁS R. VÁZQUEZ-RODRÍGUEZ, \\ INMACULADA C. MORADO, BEATRIZ MARÍ-ALFONSO, CARMEN GÓMEZ-VAQUERO, \\ JOSÉ A. MIRANDA-FILLOY, JAVIER NARVAEZ, NORBERTO ORTEGO-CENTENO, RICARDO BLANCO, \\ BENJAMÍN FERNÁNDEZ-GUTIÉRREZ, JAVIER MARTÍN, and MIGUEL A. GONZÁLEZ-GAY
}

\begin{abstract}
Objective. To assess the potential association between CD40 rs1883832 polymorphism and biopsy-proven giant cell arteritis (GCA). We also studied the influence of the polymorphism on phenotypic expression of this vasculitis, in particular the development of visual ischemic manifestations. Methods. Three hundred five Spanish patients with biopsy-proven GCA and 788 matched controls were assessed. DNA from patients and controls was obtained from peripheral blood. Samples were genotyped for the $C D 40 \mathrm{rs} 1883832 \mathrm{C} / \mathrm{T}$ polymorphism using a predesigned TaqMan allele discrimination assay and by polymerase chain reaction amplification.

Results. Patients with GCA showed a trend toward a higher frequency of the minor allele homozygote of rs 1883832 (TT) compared to healthy controls $(12.1 \%$ vs $8.3 \%$, respectively; $\mathrm{p}=0.05$, OR $1.54,95 \%$ CI $0.98-2.40)$. Also, a marginally significant increased frequency of the minor allele $\mathrm{T}$ was observed in patients with GCA who had visual ischemic manifestations (36.9\%) compared to those without visual ischemic manifestations $(27.7 \%$; $p=0.04$, OR $1.53,95 \%$ CI 0.99-2.34). In this regard, patients with GCA carrying the minor allele T (either TT or TC) experienced visual ischemic manifestations more commonly than those carrying the CC genotype ( $58.5 \%$ vs $44.2 \%$; $=0.04$, OR $1.78,95 \%$ CI $0.99-3.22$ ).

Conclusion. Our results suggest a potential implication of the CD4O rs $1883832 \mathrm{C} / \mathrm{T}$ polymorphism in susceptibility to visual ischemic manifestations in individuals with biopsy-proven GCA. (First Release August 1 2010; J Rheumatol 2010;37:2076-80; doi:10.3899/jrheum.100362)
\end{abstract}

Key Indexing Terms:

GIANT CELL ARTERITIS

CD40 GENE POLYMORPHISM

\begin{tabular}{crr}
\multicolumn{2}{c}{ TEMPORAL ARTERY BIOPSY } & GENETICS \\
RS1883832 & VISUAL ISCHEMIC MANIFESTATIONS
\end{tabular}

Giant cell arteritis (GCA) is the most common type of systemic vasculitis in Western countries in individuals over age $50^{1,2}$. The immune attack, affecting medium-size and large arteries, leads to damage of the wall structures and to rapid concentric hyperplasia of the intima, followed by luminal occlusion $^{3,4}$. Clinical manifestations reflect end-organ ischemia, including blindness, jaw claudication, or stroke. GCA is a complex polygenic disease ${ }^{5}$. Various gene polymorphisms have been associated with either disease susceptibility $5,6,7$ or a higher risk of severe ischemic complications ${ }^{8,9}$.
From the Instituto de Parasitología y Biomedicina López-Neyra, CSIC and the Department of Internal Medicine, Hospital Clínico San Cecílio, Granada; Department of Rheumatology, Hospital Clinico San Carlos and the Department of Rheumatology, Hospital de la Princesa, Madrid; Department of Rheumatology, Hospital Xeral-Calde, Lugo; Department of Internal Medicine, Corporació Sanitaria Parc Taulí, Instituto Universitario Parc Tauli, UAB, Sabadell; Department of Rheumatology, Hospital Universitario de Bellvitge-IDIBELL, L'Hospitalet de Llobregat, Barcelona; and Department of Rheumatology, Hospital Universitario Marqués de Valdecilla, IFIMAV, Santander, Spain.

Supported by 2 grants from Fondo de Investigaciones Sanitarias PI06-0024 and PS09/00748 (Spain); and partially supported by RETICS Program, RD08/0075 (RIER) from Instituto de Salud Carlos III.

L. Rodríguez-Rodríguez, MD, Instituto de Parasitología y Biomedicina López-Neyra, CSIC, and Department of Rheumatology, Hospital Clinico San Carlos; S. Castañeda, MD, PhD, Department of Rheumatology, Hospital de la Princesa; T.R. Vázquez-Rodríguez, MD;

J.A. Miranda-Filloy, MD, Department of Rheumatology, Hospital
Xeral-Calde; I.C. Morado, MD; B. Fernández-Gutiérrez, $M D, P h D$, Department of Rheumatology, Hospital Clinico San Carlos; B. Mari-Alfonso, MD, Department of Internal Medicine, Corporació Sanitaria Parc Tauli, Instituto Universitario Parc Taulí, UAB; C. Gómez-Vaquero, MD, PhD; J. Narvaez, MD, PhD, Department of Rheumatology, Hospital Universitario de Bellvitge-IDIBELL, L'Hospitalet de Llobregat; N. Ortego-Centeno, MD, PhD, Department of Internal Medicine, Hospital Clínico San Cecílio; J. Martín, MD, PhD, Instituto de Parasitología y Biomedicina López-Neyra, CSIC; R. Blanco, MD, PhD; M.A. González-Gay, MD, PhD, Department of Rheumatology, Hospital Universitario Marqués de Valdecilla, IFIMAV.

Dr. González-Gay and Dr. Martín shared authorship in this study. Address correspondence to Dr. M.A. González-Gay, Rheumatology Service, Hospital Universitario Marqués de Valdecilla, IFIMAV, Avda. de Valdecilla, s/n, 39008 Santander, Spain.

E-mail:miguelaggay@hotmail.com

Accepted for publication May 4, 2010. 
GCA inflammatory lesions infiltrate all layers of the arterial wall, and are composed of $\mathrm{T}$ cells, dendritic cells (DC), highly activated macrophages, and in some cases multinucleated giant cells ${ }^{10}$. However, B cell infiltration is rare $^{11}$.

CD40 is a type I transmembrane protein receptor of the tumor necrosis factor (TNF) superfamily ${ }^{12}$. Activation of CD4O results in binding to TNF receptor-associated factors $^{13}$ and upregulation of proinflammatory genes ${ }^{14,15}$. Various studies support an important role of this moiety in vascular wall inflammation: $C D 40$ is constitutively expressed in vascular wall cells such as endothelial cells (EC) and smooth muscle cells (SMC) ${ }^{16}$, macrophages, DC, and fibroblasts. $C D 40 / C D 4 O L$ interactions on the $\mathrm{EC}$ result in endothelium and SMC activation and expression of adhesion molecules ${ }^{17}$, promoting leukocyte recruitment and migration into tunica media. CD40 upregulates expression of local vascular endothelial growth factor and basic fibroblast growth factor ${ }^{18}$, promoting in vivo angiogenesis (a major structural alteration in the inflamed tunica media is the formation of blood vessels) ${ }^{19}$. CD40/CD40L has a role in DC/T cell interactions inside the vascular wall ${ }^{20}: C D 40 L$ on activated $\mathrm{T}$ cells interacts with $C D 40$ on DC, enhancing several costimulatory ligands on the DC that interact with $\mathrm{T}$ cell costimulatory receptors, promoting a positive feedback loop that drives differentiation ${ }^{21}$. $C D 40$ is a major mechanism involved in interleukin 12 (IL-12) production by $\mathrm{DC}^{22}$. In turn, IL-12 is dominant in directing the development of naive CD4 $\mathrm{T}$ cells into $\mathrm{T}$ helper (Th)1 cells that produce high amounts of interferon- $\gamma(\text { IFN- } \gamma)^{23}$. IFN- $\gamma$ tissue concentration correlates with the degree of intimal thickening, the extent of neovascularization, and the formation of multi-nucleated giant cells ${ }^{19}$.

There is a single-nucleotide polymorphism located in the 5' untranslated region (Kozak sequence) of the $C D 40$ gene $(-1 \mathrm{C} / \mathrm{T}, \mathrm{rs} 1883832)$. Its major allele has been associated to Graves' disease $^{24}$. Also, the major allele of another CD40 polymorphism (rs4810485), in almost complete linkage disequilibrium with rs1883832 $\left(\mathrm{r}^{2}=0.95\right)$, has been associated with rheumatoid arthritis (RA) ${ }^{25}$.

The $C D 40$ rs 1883832 major allele has been associated with an increased translational efficiency of nascent $C D 40$ mRNA transcripts ${ }^{26}$, resulting in an increase of $C D 40$ expression at the cell surface ${ }^{27}$.

$C D 40$ is known to be a regulator of retinal inflammation and neurovascular degeneration ${ }^{28}$. However, to our knowledge, no previous studies have linked the $C D 40$ rs 1883832 polymorphism with ophthalmological diseases. Taking into account this evidence, we aimed to assess the potential association between the rs1883832 CD40 polymorphism and biopsy-proven GCA. We also studied whether this polymorphism might influence the phenotypic expression of this vasculitis, in particular the development of visual ischemic manifestations.

\section{MATERIAL AND METHODS}

Patients. Three hundred five patients diagnosed with biopsy-proven GCA were recruited from departments of Rheumatology or Internal Medicine located in 5 Spanish cities: Lugo (Hospital Xeral-Calde), Madrid (Hospital Clínico San Carlos and Hospital de la Princesa), Barcelona (Hospital Universitario de Bellvitge), Sabadell (Hospital de Sabadell), and Granada (Hospital Clínico San Cecilio). A control population composed of 788 healthy controls from the corresponding cities matched by age and sex with patients with GCA was also assessed. All patients with GCA had a positive temporal artery biopsy showing disruption of the internal elastic laminae with infiltration of mononuclear cells into the arterial wall with or without giant cells ${ }^{29}$. Also, all of them met the 1990 American College of Rheumatology criteria for the classification of $\mathrm{GCA}^{30}$. Patients and controls all provided written informed consent. We obtained approval for the study from the local ethics committees.

Clinical ischemic manifestations were assessed that occurred in the time from the onset of GCA symptoms to 1 month after the onset of corticosteroid therapy ${ }^{31,32}$. The manifestations were considered to be present based on established definitions and consisted of the presence of visual ischemic manifestations ${ }^{33}$ and severe ischemic complications ${ }^{34,35}$. We also assessed the presence of polymyalgia rheumatica (PMR) based on reported definitions ${ }^{34,35}$.

Genotyping methods. DNA from patients and controls was obtained from peripheral blood, using standard methods. Samples were genotyped for the CD40 (-1C/T) rs1883832 polymorphism using a TaqMan 5' allele discrimination assay (Applied Biosystems, Foster City, CA, USA). Allele-specific probes were labeled with the fluorescent dyes VIC and FAM. Polymerase chain reaction (PCR) was carried out in a total reaction volume of $4 \mu 1$ with the following amplification protocol: denaturation at $95^{\circ} \mathrm{C}$ for $10 \mathrm{~min}$, followed by 45 cycles of denaturation at $92^{\circ} \mathrm{C}$ for $15 \mathrm{~s}$, and finished with annealing and extension at $60^{\circ} \mathrm{C}$ for $1 \mathrm{~min}$. Post-PCR, the genotype of each sample was attributed automatically by measuring the allelic-specific fluorescence on ABI Prism 7900 Sequence Detection Systems using SDS 2.3 software for allelic discrimination (Applied Biosystems) ${ }^{36}$. Duplicate samples and negative controls were included to ensure accuracy of genotyping. Statistical analysis. We used the chi-square test and Fisher's exact test for Hardy-Weinberg equilibrium and statistical analysis to compare allelic and genotypic distributions. Odds ratios and 95\% CI were calculated according to Woolf's method using the Statcalc program (Epi-Info 2002, Centers for Disease Control and Prevention, Atlanta, GA, USA). P values $<0.05$ were considered statistically significant.

\section{RESULTS}

The median age at the time of disease diagnosis in this series of 305 patients with biopsy-proven GCA was 75 years (interquartile range 70-79 yrs). Women $(\mathrm{n}=209 ; 68.5 \%)$ outnumbered men. Headache was the most common feature $(\mathrm{n}=243 ; 79.7 \%)$. An abnormal temporal artery on physical examination was observed in $168(55.1 \%)$ patients. Also, $146(47.9 \%)$ had PMR. Jaw claudication occurred in 127 $(41.6 \%)$. Visual ischemic manifestations were observed in $65(21.3 \%)$ patients. Fourteen (4.6\%) experienced a stroke. Severe ischemic complications (defined if at least 1 of the following was observed: visual ischemic manifestations, cerebrovascular accidents, jaw claudication, or limb claudication of recent onset) were found in 163 (53.4\%) patients.

No evidence of departure from Hardy-Weinberg equilibrium was observed in controls. The case:control ratio was $1: 2.5$. The power of this study for finding a difference between patients with GCA and healthy controls was 
between $69 \%$ and $98 \%$, with an estimated OR between 1.5 and 2.0, a type I error rate of 0.05 , a dominant inheritance mode and $0.0001 \%$ of population risk.

Influence of CD40 rs1883832 polymorphism in the susceptibility to GCA. Patients with GCA showed a trend toward a higher frequency of the minor allele homozygote of rs1883832 (TT) compared to controls $(12.1 \%$ vs $8.3 \%$, respectively; $\mathrm{p}=0.05$, OR $1.54,95 \%$ CI $0.98-2.40$; Table $1)$. In this regard, the frequency of the minor allele $\mathrm{T}$ was increased among patients with GCA compared to controls but the difference did not achieve statistical significance $(29.7 \%$ vs $27.0 \%$, respectively; $\mathrm{p}=0.20)$.

Genotype and allele frequencies of CD40 rs 1883832 polymorphism according to patients' clinical manifestations. To further investigate the potential role of the CD40 rs1883832 polymorphism in the phenotypic expression of this vasculitis, patients with GCA were stratified according to the occurrence of PMR, visual ischemic complications, or severe ischemic manifestations, and then assessed for the allele and genotype distribution (Table 2). No significant differences were found in the allele or genotype frequencies between patients with GCA, either with or without PMR (Table 2). However, a marginally significant increased frequency of the minor allele $\mathrm{T}$ was observed in patients who had visual ischemic manifestations (36.9\%) compared to patients who did not have visual ischemic manifestations (27.7\%; $\mathrm{p}=0.04$, OR $1.53,95 \%$ CI 0.99-2.34). However, the correction of $\mathrm{p}$ value for the number of alleles tested yielded a $\mathrm{p}$ value for the allele $\mathrm{T}$ association with visual ischemic manifestations slightly out of the range of significance $(\mathrm{p}=0.08)$.

Also, patients with GCA carrying the minor allele $\mathrm{T}$ (either TT or TC) experienced visual ischemic manifestations more commonly than those carrying the $\mathrm{CC}$ genotype (58.5\% vs $44.2 \%$, respectively; $\mathrm{p}=0.04$, OR $1.78,95 \%$ CI 0.99-3.22). Moreover, there was a nonsignificant trend toward a higher frequency of the minor allele $\mathrm{T}$ among patients with severe ischemic complications $(32.5 \%)$ compared to those without these complications $(26.4 \%$; $\mathrm{p}=0.10$, OR $1.34,95 \%$ CI $0.93-1.94)$. In this regard, the frequency of individuals carrying the minor allele $\mathrm{T}$ was increased among patients who had severe ischemic complications $(52.1 \%)$ compared to those without severe ischemic compli-

Table 1. Genotype and allele frequencies of rs1883832 CD40 gene polymorphism in healthy controls and patients with GCA.

\begin{tabular}{lcccc}
\hline & $\begin{array}{c}\text { Controls, } \\
\mathrm{n}=788(\%)\end{array}$ & $\begin{array}{c}\text { GCA, } \\
\mathrm{n}=305(\%)\end{array}$ & $\mathrm{p}$ & OR (95\% CI) \\
\hline $\mathrm{CC}+\mathrm{CT}$ & $723(91.7)$ & $268(87.9)$ & & \\
$\mathrm{TT}$ & $65(8.3)$ & $37(12.1)$ & 0.05 & $1.54(0.98-2.40)$ \\
& $2 \mathrm{n}=1576$ & $2 \mathrm{n}=610$ & & \\
$\mathrm{C}$ & $1151(73.0)$ & $429(70.3)$ & & \\
$\mathrm{T}$ & $425(27.0)$ & $181(29.7)$ & 0.20 & $1.14(0.92-1.41)$ \\
\hline
\end{tabular}

cations $(41.5 \%)$ but the difference remained slightly out of the range of significance $(\mathrm{p}=0.065$, OR $1.53,95 \% \mathrm{CI}$ 0.95-2.48).

Comparison of patients with GCA according to the presence or absence of other clinical manifestations did not yield statistically significant differences (data not shown).

\section{DISCUSSION}

We analyzed for the first time the potential implication of the $C D 40 \mathrm{rs} 1883832 \mathrm{C} / \mathrm{T}$ polymorphism in susceptibility to biopsy-proven GCA. We observed a nonsignificant trend for association between the genotype TT (homozygous for the minor allele T) and biopsy-proven GCA. However, differences in allelic frequencies between patients with GCA and healthy controls were smaller. Our data, assessing the largest series of GCA included in a genetic study, also disclosed a marginally significant increased frequency of the minor allele $\mathrm{T}$ of the $C D 40 \mathrm{rs} 1883832$ polymorphism in the subgroup of patients with GCA who experienced visual ischemic manifestations. We also observed a higher frequency of the minor allele $\mathrm{T}$ among patients with severe ischemic complications, but the differences were smaller and did not reach statistical significance, probably because of an insufficient sample size, as GCA is a relatively uncommon disease.

The $C D 40 \mathrm{rs} 1883832 \mathrm{C} / \mathrm{T}$ polymorphism has previously been associated with Graves' disease ${ }^{24,37}$ and multiple sclerosis $^{38}$. Another $C D 40$ polymorphism (rs4810485) in linkage disequilibrium with $\mathrm{rs} 1883832\left(\mathrm{r}^{2}=0.95\right)$ has been associated with an increased risk for $\mathrm{RA}^{25}$ and a higher rate of joint destruction in patients with this chronic inflammatory rheumatic disease ${ }^{39}$. In both Graves' disease and RA the allele associated with a higher risk of disease susceptibility or with worse outcome was the major allele $\mathrm{C}$. This major allele $\mathrm{C}$ has been associated with a higher expression of the CD40 moiety in cell surface of peripheral blood mononuclear cells, B cells, and platelets ${ }^{26,27,40}$. However, in keeping with data reported in patients with multiple sclerosis, in our series of GCA the allele that seems to be associated with a worse outcome (manifested by increased risk of visual ischemic complications) was the minor allele $\mathrm{T}$.

As discussed, arterial wall inflammation leads to rapid concentric hyperplasia of the intima, followed by luminal occlusion in patients with $\mathrm{GCA}^{3,4}$. Because of the potential role played by $C D 40 / C D 40 \mathrm{~L}$ interaction in the stimulus of IL-12 secretion by local DC, it is possible that the smaller number of $C D 40$ moieties on the cell surface associated with the minor allele $\mathrm{T}$ of the rs 1883832 polymorphism $^{26}$ might predispose to a higher risk of visual ischemic manifestations in patients with GCA. IL-12 is dominant in directing the development of naive CD4 T cells into Th1 cells that produce high amounts of IFN- $\gamma$, a key cytokine in GCA, whose tissue concentration correlates with the degree of intimal thickening, the extent of neovascularization, and the 
Table 2. Association between the rs 1883832 CD40 gene polymorphism and specific clinical manifestations of GCA.

\begin{tabular}{lcccc}
\hline & With, $\mathrm{n}(\%)$ & Without, $\mathrm{n}(\%)$ & $\mathrm{p}$ & OR $(95 \% \mathrm{CI})$ \\
\hline Polymyalgia rheumatica & & & & \\
CC & $80(54.8)$ & $81(50.9)$ & & 1 -reference \\
CT+TT & $66(45.2)$ & $78(49.1)$ & 0.50 & $0.86(0.53-1.38)$ \\
C & $207(70.9)$ & $222(69.8)$ & & 1 -reference \\
T & $85(29.1)$ & $96(30.2)$ & 0.77 & $0.95(0.66-1.37)$ \\
Visual ischemic manifestations & & & & \\
CC & $27(41.5)$ & $134(55.8)$ & & 1 -reference \\
CT+TT & $38(58.5)$ & $106(44.2)$ & 0.04 & $1.78(0.99-3.22)$ \\
C & $82(63.1)$ & $347(72.3)$ & & 1 -reference \\
T & $48(36.9)$ & $133(27.7)$ & 0.04 & $1.53(0.99-2.34)$ \\
Severe ischemic complications & & & & \\
CC & $78(47.9)$ & $83(58.5)$ & & 1 -reference \\
CT+TT & $85(52.1)$ & $59(41.5)$ & 0.065 & $1.53(0.95-2.48)$ \\
C & $220(67.5)$ & $209(73.6)$ & & 1 -reference \\
T & $106(32.5)$ & $75(26.4)$ & 0.10 & $1.34(0.93-1.94)$ \\
\hline
\end{tabular}

formation of multinucleated giant cells ${ }^{19}$. Moreover, the source of IL-12 is highly restricted to DC that produce this cytokine after stimulation with either bacterial components such as lipopolysaccharide (LPS) or during the interaction with CD4+ T cells, because of the ligation of either $C D 40^{23}$ or MHC class II molecules on DC. LPS-induced IL-12 plays an important role in the activation of the effector mechanisms in the initial phase of immune response in infected tissues, initiating an innate resistance to the pathogen while ensuring induction of the correct class of adaptive host response $^{22}$. However, the major mechanisms involved in IL-12 induction appear to be signaling through DC surface CD40 molecules or MHC class II molecules ${ }^{22}$. Considering that GCA has been proposed to be an antigen-driven disease $^{41}$, we hypothesize that $C D 40 \mathrm{rs} 1883832 \mathrm{C} / \mathrm{T}$ polymorphism might contribute to an insufficient initial immune reaction against the antigen or antigens responsible for this vasculitis, leading to a situation in which the antigen cannot be completely eradicated, and chronically stimulates the immune system inside the arterial wall. This hypothesis agrees with previous observations in which patients with biopsy-proven GCA who suffered visual ischemic manifestations were associated with an initial lower inflammatory response ${ }^{31,42,43,44}$. The fact that subjects not carrying $C D 40$ rs1883832 minor allele $\mathrm{T}$ develop this condition may be due to the intrinsic characteristics of the antigen responsible for the disease, that is, it is difficult to eradicate completely even with a normal amount of $C D 40$ in the cell surface.

Based on our data, the presence of this genetic variant could help to identify patients with biopsy-proven GCA who have a higher risk of a worse visual outcome. Further studies in large series of patients with GCA are needed to confirm our observations.

\section{ACKNOWLEDGMENT}

We thank Sofia Vargas, Gema Robledo, and Sonia García Ruíz for pro- cessing the DNA samples. We also thank Sara Abel Liz, Maria Soledad Folgosa Rodriguez, and Ana Maria Ramos Gandoy, nurses from the Rheumatology Division, Hospital Xeral-Calde, Lugo, Spain, for help in collection of samples.

\section{REFERENCES}

1. Salvarani C, Cantini F, Boiardi L, Hunder GG. Polymyalgia rheumatica and giant-cell arteritis. N Engl J Med 2002;347:261-71.

2. Gonzalez-Gay MA, Vazquez-Rodriguez TR, Lopez-Diaz MJ, Miranda-Filloy JA, Gonzalez-Juanatey C, Martin J, et al. Epidemiology of giant cell arteritis and polymyalgia rheumatica. Arthritis Rheum 2009;61:1454-61.

3. Weyand CM, Goronzy JJ. Arterial wall injury in giant cell arteritis. Arthritis Rheum 1999;42:844-53.

4. Weyand CM. The Dunlop-Dottridge Lecture: The pathogenesis of giant cell arteritis. J Rheumatol 2000;27:517-22.

5. Gonzalez-Gay MA, Amoli MM, Garcia-Porrua C, Ollier WE. Genetic markers of disease susceptibility and severity in giant cell arteritis and polymyalgia rheumatica. Semin Arthritis Rheum 2003;33:38-48.

6. Weyand CM, Hunder NN, Hicok KC, Hunder GG, Goronzy JJ. HLA-DRB1 alleles in polymyalgia rheumatica, giant cell arteritis, and rheumatoid arthritis. Arthritis Rheum 1994;37:514-20.

7. Rodriguez-Pla A, Beaty TH, Savino PJ, Eagle RC Jr, Seo P, Soloski MJ. Association of a nonsynonymous single-nucleotide polymorphism of matrix metalloproteinase 9 with giant cell arteritis. Arthritis Rheum 2008;58:1849-53.

8. Rueda B, Lopez-Nevot MA, Lopez-Diaz MJ, Garcia-Porrua C, Martin J, Gonzalez-Gay MA. A functional variant of vascular endothelial growth factor is associated with severe ischemic complications in giant cell arteritis. J Rheumatol 2005;32:1737-41.

9. Gonzalez-Gay MA, Hajeer AH, Dababneh A, Garcia-Porrua C, Amoli MM, Llorca J, et al. Interferon-gamma gene microsatellite polymorphisms in patients with biopsy-proven giant cell arteritis and isolated polymyalgia rheumatica. Clin Exp Rheumatol 2004;22 Suppl 36:S18-20.

10. Cid MC, Campo E, Ercilla G, Palacin A, Vilaseca J, Villalta J, et al. Immunohistochemical analysis of lymphoid and macrophage cell subsets and their immunologic activation markers in temporal arteritis. Influence of corticosteroid treatment. Arthritis Rheum 1989;32:884-93.

11. Martinez-Taboada V, Brack A, Hunder GG, Goronzy JJ, Weyand CM. The inflammatory infiltrate in giant cell arteritis selects 
against B lymphocytes. J Rheumatol 1996;23:1011-4.

12. Anand SX, Viles-Gonzalez JF, Badimon JJ, Cavusoglu E, Marmur JD. Membrane-associated CD40L and SCD40L in atherothrombotic disease. Thromb Haemost 2003;90:377-84.

13. Bishop GA. The multifaceted roles of TRAFs in the regulation of B-cell function. Nat Rev Immunol 2004;4:775-86.

14. Chen Y, Chen J, Xiong Y, Da Q, Xu Y, Jiang X, et al Internalization of CD40 regulates its signal transduction in vascular endothelial cells. Biochem Biophys Res Commun 2006;345:106-17.

15. Iezzi G, Sonderegger I, Ampenberger F, Schmitz N, Marsland BJ, Kopf M. CD40-CD40L cross-talk integrates strong antigenic signals and microbial stimuli to induce development of IL-17-producing CD4+ T cells. Proc Natl Acad Sci USA 2009;106:876-81.

16. Schonbeck U, Libby P. The CD40/CD154 receptor/ligand dyad. Cell Mol Life Sci 2001;58:4-43.

17. Schonbeck U, Gerdes N, Varo N, Reynolds RS, Horton DB, Bavendiek U, et al. Oxidized low-density lipoprotein augments and 3-hydroxy-3-methylglutaryl coenzyme A reductase inhibitors limit CD40 and CD40L expression in human vascular cells. Circulation 2002;106:2888-93.

18. Leroyer AS, Rautou PE, Silvestre JS, Castier Y, Leseche G, Devue $\mathrm{C}$, et al. CD40 ligand+ microparticles from human atherosclerotic plaques stimulate endothelial proliferation and angiogenesis a potential mechanism for intraplaque neovascularization. J Am Coll Cardiol 2008;52:1302-11.

19. Kaiser M, Younge B, Bjornsson J, Goronzy JJ, Weyand CM. Formation of new vasa vasorum in vasculitis. Production of angiogenic cytokines by multinucleated giant cells. Am J Pathol 1999;155:765-74.

20. Pryshchep O, Ma-Krupa W, Younge BR, Goronzy JJ, Weyand CM. Vessel-specific Toll-like receptor profiles in human medium and large arteries. Circulation 2008;118:1276-84.

21. Quezada SA, Jarvinen LZ, Lind EF, Noelle RJ. CD40/CD154 interactions at the interface of tolerance and immunity. Annu Rev Immunol 2004;22:307-28.

22. Reis e Sousa C, Hieny S, Scharton-Kersten T, Jankovic D, Charest $\mathrm{H}$, Germain RN, et al. In vivo microbial stimulation induces rapid CD40 ligand-independent production of interleukin 12 by dendritic cells and their redistribution to T cell areas. J Exp Med 1997;186:1819-29.

23. Cella M, Scheidegger D, Palmer-Lehmann K, Lane P, Lanzavecchia A, Alber G. Ligation of CD40 on dendritic cells triggers production of high levels of interleukin-12 and enhances T cell stimulatory capacity: T-T help via APC activation. J Exp Med 1996; 184:747-52.

24. Kurylowicz A, Kula D, Ploski R, Skorka A, Jurecka-Lubieniecka B, Zebracka J, et al. Association of CD40 gene polymorphism (C-1T) with susceptibility and phenotype of Graves' disease. Thyroid 2005;15:1119-24.

25. Raychaudhuri S, Remmers EF, Lee AT, Hackett R, Guiducci C, Burtt NP, et al. Common variants at CD40 and other loci confer risk of rheumatoid arthritis. Nat Genet 2008;40:1216-23.

26. Jacobson EM, Concepcion E, Oashi T, Tomer Y. A Graves' disease-associated Kozak sequence single-nucleotide polymorphism enhances the efficiency of CD40 gene translation: a case for translational pathophysiology. Endocrinology 2005;146:2684-91.

27. Tian C, Qin W, Li L, Zheng W, Qiu F. A common polymorphism in CD40 Kozak sequence $(-1 \mathrm{C} / \mathrm{T})$ is associated with acute coronary syndrome. Biomed Pharmacother 2010;64:191-4.

28. Portillo JA, Van Grol J, Zheng L, Okenka G, Gentil K, Garland A, et al. CD40 mediates retinal inflammation and neurovascular degeneration. J Immunol 2008;181:8719-26.
29. Gonzalez-Gay MA, Garcia-Porrua C, Llorca J, Gonzalez-Louzao C, Rodriguez-Ledo P. Biopsy-negative giant cell arteritis: clinical spectrum and predictive factors for positive temporal artery biopsy. Semin Arthritis Rheum 2001;30:249-56.

30. Hunder GG, Bloch DA, Michel BA, Stevens MB, Arend WP, Calabrese LH, et al. The American College of Rheumatology 1990 criteria for the classification of giant cell arteritis. Arthritis Rheum 1990;33:1122-8.

31. Lopez-Diaz MJ, Llorca J, Gonzalez-Juanatey C, Pena-Sagredo JL, Martin J, Gonzalez-Gay MA. The erythrocyte sedimentation rate is associated with the development of visual complications in biopsy-proven giant cell arteritis. Semin Arthritis Rheum 2008;38:116-23.

32. Gonzalez-Gay MA, Vazquez-Rodriguez TR, Gomez-Acebo I, Pego-Reigosa R, Lopez-Diaz MJ, Vazquez-Trinanes MC, et al. Strokes at time of disease diagnosis in a series of 287 patients with biopsy-proven giant cell arteritis. Medicine (Baltimore) 2009;88:227-35.

33. Gonzalez-Gay MA, Lopez-Diaz MJ, Barros S, Garcia-Porrua C, Sanchez-Andrade A, Paz-Carreira J, et al. Giant cell arteritis: laboratory tests at the time of diagnosis in a series of 240 patients. Medicine (Baltimore) 2005;84:277-90.

34. Gonzalez-Gay MA, Barros S, Lopez-Diaz MJ, Garcia-Porrua C, Sanchez-Andrade A, Llorca J. Giant cell arteritis: disease patterns of clinical presentation in a series of 240 patients. Medicine (Baltimore) 2005;84:269-76.

35. Gonzalez-Gay MA, Pineiro A, Gomez-Gigirey A, Garcia-Porrua C, Pego-Reigosa R, Dierssen-Sotos T, et al. Influence of traditional risk factors of atherosclerosis in the development of severe ischemic complications in giant cell arteritis. Medicine (Baltimore) 2004;83:342-7.

36. Orozco G, Alizadeh BZ, Delgado-Vega AM, Gonzalez-Gay MA, Balsa A, Pascual-Salcedo D, et al. Association of STAT4 with rheumatoid arthritis: a replication study in three European populations. Arthritis Rheum 2008;58:1974-80.

37. Jacobson EM, Huber AK, Akeno N, Sivak M, Li CW, Concepcion E, et al. A CD40 Kozak sequence polymorphism and susceptibility to antibody-mediated autoimmune conditions: the role of CD40 tissue-specific expression. Genes Immun 2007;8:205-14.

38. Buck D, Kroner A, Rieckmann P, Maurer M, Wiendl H. Analysis of the $\mathrm{C} / \mathrm{T}(-1)$ single nucleotide polymorphism in the CD40 gene in multiple sclerosis. Tissue Antigens 2006;68:335-8.

39. van der Linden MP, Feitsma AL, le Cessie S, Kern M, Olsson LM, Raychaudhuri S, et al. Association of a single-nucleotide polymorphism in CD40 with the rate of joint destruction in rheumatoid arthritis. Arthritis Rheum 2009;60:2242-7.

40. Yan J, Wang C, Du R, Liu P, Chen G. Association analysis of CD40 gene polymorphism with acute coronary syndrome. Clin Exp Med 2010 Feb 2. [Epub ahead of print].

41. Weyand CM, Schonberger J, Oppitz U, Hunder NN, Hicok KC, Goronzy JJ. Distinct vascular lesions in giant cell arteritis share identical T cell clonotypes. J Exp Med 1994;179:951-60.

42. Cid MC, Font C, Oristrell J, de la Sierra A, Coll-Vinent B, Lopez-Soto A, et al. Association between strong inflammatory response and low risk of developing visual loss and other cranial ischemic complications in giant cell (temporal) arteritis. Arthritis Rheum 1998;41:26-32.

43. Gonzalez-Gay MA, Garcia-Porrua C, Llorca J, Hajeer AH, Branas F, Dababneh A, et al. Visual manifestations of giant cell arteritis. Trends and clinical spectrum in 161 patients. Medicine (Baltimore) 2000;79:283-92.

44. Cid MC, Hernandez-Rodriguez J, Esteban MJ, Cebrian M, Gho YS Font $\mathrm{C}$, et al. Tissue and serum angiogenic activity is associated with low prevalence of ischemic complications in patients with giant-cell arteritis. Circulation 2002;106:1664-71. 